\title{
HATE CRIMES: THE ULTIMATE ANATHEMATIC CRIMES
}

\section{Introduction}

Hate crimes are grave offences that involve violations of human rights and humanitarian law. Hate crimes are offences which are motivated by bias or prejudice against a person based on their ethnicity, race, colour, sexual orientation, gender, handicap or religion (Davenport Basic Criminal Law: The Constitution, Procedure and Crimes 2ed (2009) 129; and Scotting "Hate Crimes and the Need for Stronger Federal Legislation" 200134 Akron LR 853857 ). If one considers the severity of these crimes and the cumulative consequences thereof, it is evident that these crimes do not get as much concern as they should (Hall Hate Crime 2ed (2013) 190). The conduct in this type of crime targets groups of individuals based on their actual or perceived membership in a particular group. The crimes are profoundly influenced and driven by the collective action of its perpetrators, also members of a group, who regard themselves as superior (see, eg, the case of Wisconsin v Mitchell 508 US (1993)). The interplay between individual action and group membership is central to these crimes in so far as this interplay engenders thorny questions of responsibility and punishment. This note intends to explore the manner in which South African and American criminal law give impetus to the criminalization of the above-mentioned collective wrongdoing. It is important to consider the handling of hate crimes in American society as South Africa has a similar history of racial discrimination to that in the United States. The first part of the note will delineate the concept of hate crime, while the second part will examine hate crimes from a South African as well as American criminal-law perspective. Lastly, the punishment of perpetrators of prejudice-motivated crimes is investigated as a final intervention in combating this manifestation in South Africa.

\section{Incidence and defining a hate crime}

Hate crimes have been defined as

"a crime in which the defendant intentionally selects a victim, or in the case of a property crime, the property that is the object of the crime, because of the actual or perceived race, color, religion, national origin, ethnicity, gender, disability, or sexual orientation of any person" (Scotting 200134 Akron LR 857).

Hate crimes are inextricably linked to other criminal offences such as assault or murder as these crimes must be committed, but with a bias or prejudice motive in order to qualify as a hate crime. The motive behind the crime is usually irrelevant in establishing whether a person acted with intention, although motive is normally considered in the context of 
sentencing (Snyman Criminal Law 5ed (2008) 190). However, in the case of hate crimes, motive is in fact relevant as a requirement (Davenport Basic Criminal Law: The Constitution, Procedure and Crimes 129). The issue of motive forms the foundation for a typology of victimization such as those victims intentionally selected because of gender, race, colour, religion, national origin, ethnicity, disability or sexual orientation. A hate crime encapsulates the offender's "attitudes, values and character" (Jacobs and Potter "Hate Crimes: A Critical Perspective" 199722 Crime \& Just 12 2).

With regard to the characteristics of perpetrators, it has been established that the perpetrators form part of a "distinctive ethos of male-youth culture" (Oakley Tackling Racist and Xenophobic Violence in Europe: Review and Practical Guidance (1996) 47). From research undertaken in the United States, the crime is perpetrated against strangers by individual ("Ione wolves") or multiple offenders, who are usually males between the ages of 14-24 years with low self-esteem, who have a tendency to despise stereotypical groups of people (Scotting 200134 Akron LR 859-860). The motivations for the perpetration of hate crimes are commonly cited as the following: power and domination; a belief that the victim is deserving of punishment; insecurity or resentment; and means of expressing their anger at a class of people (Harris "Arranging Prejudice: Exploring Hate Crime in post-apartheid South Africa" 2004 Race and Citizenship in Transition Series 14). An interesting question is how strong should the causal nexus be in order to be considered as motivated by bias? As Jacobs and Potter mention in the determination of a causal relationship between the criminal conduct and the bias, if the criminal act should be "wholly motivated by prejudice" then the incidence of hate crimes will be small, whereas if the criminal act should merely be partially motivated by prejudice (nearly all) "intergroup crimes" have the potential to be classified as hate crimes (1997 22(1) Crime \& Just 4-5).

According to widespread anecdotal evidence (by mainly individual witnesses' testimony), hate crimes mainly manifest themselves in South Africa in the form of targeting foreign nationals or immigrants who are blamed for social ills ("xenophobic violence"), as corrective rape against black lesbians, racial violence and attacks against South African farmers. Specific examples of high-profile hate-crime incidents in South Africa include incidents such as where policemen set their dogs onto Mozambicans whom they also beat and verbally abused with derogatory racial comments, xenophobic attacks on foreign shopowners in townships in almost all the provinces and the case of Barend Strydom, a "lone wolf", who opened fire on all black persons in the vicinity of Strydom Square, murdering 7 people and injuring 16 persons. He received 8 death sentences but was granted amnesty.

Hate crimes are inclined to be more violent than other crimes and the victims of hate crimes tend to be exposed to severe cruelty and torture which may manifest in mutilations, skull injuries or stabbing of the victim (Scotting 200134 Akron LR 861). Well-known examples from the United States are the accounts of Shepard, Byrd and Lepine: 
- Matthew Shepard was a gay student who was brutally beaten, tied to a fence and left to die. He succumbed to his injuries a few days later in hospital.

- James Byrd was an African-American man who was beaten and then chained by his ankles to the bumper of a pickup truck and dragged. Police found different body parts on the road and his head in a ditch.

- Lepine shot 14 women in a class at the University of Montreal and committed suicide. Before killing the women he screamed out that he hated feminists, and left a note on his body, which read that feminists had always ruined his life.

These incidents provided the fuel for change and hate crime legislation in the US (Matthew Shepard and James Byrd Jr Hate Crimes Prevention Act 18 USC § 249 (2010); and Scotting 200134 Akron LR 853 fn4-fn6).

\section{$3 \quad$ Prosecuting hate crimes in South Africa}

There is currently no dedicated legislation which is directly tailored to specifically address the prosecution of hate crimes in South Africa. The Department of Justice and Constitutional Development has, however, developed a draft-policy framework, titled Combating Hate Crimes, Hate Speech and Unfair Discrimination, which could be enacted in 2014. Still, aside from the Constitutional prohibition on discrimination in section 9(4) as well as the common-law crimes which would cover the underlying crime such as assault or murder, there are certain statutes that indirectly incorporate certain forms of hate crime. For example, the Promotion of Equality and Prevention of Unfair Discrimination Act 4 of 2000 provides for civil damages as a remedy (s 21(1)(d)) and prohibits discrimination on the grounds of race, gender and disability (ss 7-9). This Act also prohibits hate speech (see African National Congress $v$ Harmse: In Re Harmse $v$ Vawda (Afriforum and Another Intervening) 2011 (5) SA 460 (GSJ) 470-471), for an example and discussion on what constitutes hate speech - in this case the words "dubula ibhunu" or "shoot the boer" was considered to be hate speech and thus unconstitutional) which includes hurtful or harmful comments (s 10) and prohibits harassment (s 11). Harassment is defined as

"unwanted conduct which is persistent or serious and demeans, humiliates or creates a hostile or intimidating environment or is calculated to induce submission by actual or threatened adverse consequences and which is related to -

(a) sex, gender or sexual orientation, or

(b) a person's membership or presumed membership of a group identified by one or more of the prohibited grounds or a characteristic associated with such group (s 1)".

Other legislation which could be utilized in prosecuting hate crimes is the Protection from Harassment Act 17 of 2011, which came into force on 7 April 2013. The definition of "harassment" in this Act incorporates the causing of harm and secondly, the inspiring of the reasonable belief that harm may be caused (s 1). The harm that this act is aimed at criminalizing includes "any mental, psychological, physical or economic harm" caused (ss 2 and $11(1)(a)$ and (b)). It is clear that hate crimes would also fall squarely within 
the ambits of this crime. This Act provides a civil remedy for harassment in the form of issuing a protection order and a suspended warrant of arrest, with the two being issued at the same time, so that if the harasser contravenes the order such person may be arrested (ss 2 and 11(1)(a) and (b)). Only relatively short sentences can be imposed as the penalty for a breach of section 1 is punishable by for example 6 months' imprisonment or a fine that is limited to level 5 on the scale (s 2(2)). As South Africa only has legislation which indirectly deals with hate crimes, the next section will examine the position under the United States to establish what possibilities exist in so far as legislating hate crimes is concerned.

\section{$4 \quad$ Hate-crimes legislation in the United States}

In the United States, subject-specific legislation has been passed in an attempt to deal with hate crimes. It could be said that the first federal hatecrimes legislation was passed by the US Congress in 1871. This law was known as the Ku Klux Klan Act of 1871 (currently codified as 42 USCA §§ 1985-1986) and prohibited two or more individuals from conspiring to deprive "any person or class of persons of equal protection of the laws, or of equal privileges and immunities under the laws" (Erickson "Hate Crimes" 20056 Geo J Gender \& L 291). The first specific federal hate-crimes statute - Title 18 of the United States Code section 245 (1969) - provided for hatecrime acts whereby an offence exists where there was the use of force or the threat of force to intimidate, injure or interfere with another person due to such person's colour, race, religion or national origin (Federal Civil Rights Law 18 USC § 245). Other federal legislation included the Hate Crime Statistics Act 28 USC § 534 (1994) and the Hate Crimes Sentencing Enhancement Act 28 USC 994 § (1994); Violent Crime Control and Law Enforcement Act 1994 § 280003). The latter Act includes inter alia conduct which is motivated by race, ethnicity, colour, sexual orientation, gender and religion. The Hate Crimes Statistics Act was also passed in 1990 and hatecrime units have been created to deal with reported hate crimes (Boyd, Hamner and Berk "Motivated by Hatred or Prejudice: Categorization of HateMotivated Crimes in Two Police Division" 199630 Law \& Soc'y Rev 820). Both the two last-mentioned Acts can be regarded as alternatives to the specific hate-crimes statute by means of enhancing the offender's sentence "if it can be shown that the offender was motivated by hate or bias" beyond a reasonable doubt (Erickson 20056 Geo J Gender \& L 293; see, eg, Apprendi v New Jersey, 530 US 466, 477 (2000); and Blakely v Washington 542 US 296, 124 S Ct 2531 (2004)).

The initial federal provisions of 1969 dealing with hate crimes referred to above (18 USC § 245) did not specifically provide for hate crimes related to disability, sexual orientation or gender and was only applicable if a victim was engaged in a federally-protected activity (Scotting 200134 Akron LR 878-880) The enactment of the Matthew Shepard and James Byrd Jr Hate Crimes Prevention Act 2009 provided for a new federal hate-crime statute that was codified at 18 USC $\$ 249$ (2010) and caters for a broader category of victim that includes hate crimes related to gender, sexual orientation and disability. 
A pilot study done in the United States by the FBl's National IncidentBased Reporting System (NIBRS) measured 3000 reported hate crimes over a two-year period between 1997 and 1999. The majority of the victims were assaulted and the main motivation was racial bias, for example, in RAV v City of St Paul (505 US 377 (1992)). In this case a group of teenagers made a cross out of broken chair legs and burned this cross in the yard of an African-American family. Racial bias is closely followed by those hate crimes related to religious- and sexual orientation-related bias.

While hate crime has been defined by the Organisation for Security and Cooperation in Europe (OSCE) as "a criminal act committed with a bias motive" (OSCE Hate Crime Laws: A Practical Guide (2009) 16), there is no uniform definition of hate crimes in the United States due to the different legislative definitions of the various states. The different hate-crime legislation is not only attributable to the prejudice aspect which transmogrifies a recognized crime into a hate crime. In some cases, the reason may be related to states redefining conduct which is already a recognized crime, or regarding such conduct as an aggravated form of such recognized crime. In Pennsylvania for example, a hate crime includes any offence which is motivated by national origin, race or religion, whereas in New Jersey a predicate offence such as simple assault which is motivated by bias would qualify as a hate crime (Pa Cons Stat $\S 2710$ (a); NJ Stat Ann § 2C 12-1; also see discussion in Jacobs and Potter 199722 Crime \& Just 6; Gillis "Understanding Hate Crime Statutes and Building towards a Better System in Texas" $201340 \mathrm{Am} J$ Crim L $211 \mathrm{ff}$ for a discussion of the different state responses to hate crimes in the United States). What is interesting to note is that the term "motivation" is not usually used in statutes but the terms "by reason of" or "because of" which would actually accord with a materiallydefined crime (Jacobs and Potter 199722 Crime \& Just 10). However, the definitions seem to take on the form of substantive hate-crime statutes, statutes which increase sentences where the motivation for the crime is a prohibited bias, and reporting statutes where officials need to collate data relating to hate crimes (Fairfax "The Thin Line Between Love and Hate: Why Affinity-Based Securities and Investment Fraud Constitutes a Hate Crime" 200336 UC Davis LR 1095). Problems in proving motive are often raised as criticism of the independent existence of such crimes for reasons relating to differences in semantics relating to hate-crime definitions, that may result in difficulties in identifying whether a crime is a hate crime or not, and which may also possibly lead to different verdicts in cases with the same evidence (Meli "Hate Crime And Punishment: Why Typical Punishment Does Not Fit The Crime" 2014 U III LRev 921 928).

\section{Punishing perpetrators of hate crimes}

As there is currently no specific legislation in terms of which hate crimes in South Africa can be punished, supplementary legislation and common-law crimes have to be utilized in this regard. However, none of the existing laws, for example as the Protection from Harassment Act 17 of 2011, specifically caters for sentences in this type of crime. One solution to counteract this problem would be to increase the penalty for the crime which is committed (Jacobs and Potter 199722 Crime \& Just 34; Scotting 200134 Akron LR 
867; and for contrary view see Meli 2014 U III LRev 960-961). Currently the mandatory minimum sentences (s 51 of the Criminal Law Amendment Act 105 of 1997) do not expressly provide for this (see Karels and Naidoo "Hate Crimes against Black Lesbian South Africans: Where Race, Sexual Orientation and Gender Collide Part II" 2012 Obiter 619-620). In the United States most states have in fact increased the penalty for these crimes (Wisconsin v Mitchell 508 US 476 (1993); and Gillis 201340 Am J Crim L 202) and some states have developed substantive offences to deal with this form of offence or to even regard it as an aggravated variation of existing crimes (Scotting 200134 Akron LR 868; and Gillis 201340 Am J Crim L 203).

It is, however, clear that in the context of hate crimes, the South African courts are willing to consider this aspect in the sentencing phase as an aggravating factor (Terblanche The Guide to Sentencing in South Africa (2007) par 6.3.2). This is witnessed from a recent case that indirectly dealt with hate crimes. In S v Combrink (2012 (1) SACR 93 (SCA)), the appellant was a farmer who fired two shots at an unidentified person who was walking across farm land. The person did not respond to his calls. The first shot was fired as a warning or to intimidate the person and the second shot killed the person. The trial court convicted him of murder and sentenced him to 15 years. On appeal he received a sentence of 10 years. On a further appeal to the Supreme Court of Appeal, his conviction was confirmed and the sentence was increased to 15 years. While the case does not deal with hate crime per se, in the dictum the judges allude to this aspect and state that:

"The public interest and discrimination are not necessarily between black and white but rather between people in general who perceive others, with prejudice, to be different or inferior to them. It is this perception that the judiciary should address. As a result of avoiding the issue of racial tension some people think that: 'Judges and magistrates will not necessarily be aware that the effect of hate crimes goes far beyond the victims and serves to traumatise whole communities and damage South African society. Without the decision makers in the criminal justice system being attuned to these issues it will not be possible to properly combat hate crimes"' (102A-C).

The Court further mentions the fact that in the past many cases with a racial connotation have been dealt with but not under the heading of hate crime (eg, S v Van Wyk 1992 (1) SACR 147 (Nm); S v De Kock 1997 (2) SACR $171(\mathrm{~T})$; and $S$ v Matela 1994 (1) SACR 236 (A)). In his judgment, Poswa J, affirms that this type of conduct will be considered a hate crime as it impacts negatively on race relations in the country:

"What the court a quo did not mention, which, in my view, merits mentioning, is the fact that the appellant's conduct was adding to a series of disturbing events in which a number of African people, some of them employees of the accused persons, are shot by a number of 'white farmers' which episode definitely has a negative impact on race relations in a country with a painful history of relations between 'white' and 'black' citizens" (par 88).

In another case of $S v$ Motaung ((190/88) [1990] ZASCA 75; 1990 (4) SA 485 (AD); [1990] 2 All SA 485 (A)), the accused savagely assaulted the victim, set her alight and battered her to death on suspicion of being a police informer. This is clear from the evidence of one of the accused, who 
expressed a desire to make the deceased feel pain as she was an informant. Under cross-examination the following evidence emerged -

\footnotetext{
"And you mentioned that you were like a madperson (sic)? Yes. Especially when you used the hosepipe? Yes. Did the madness come over you because you had a feeling of hate towards this informer? Yes, because she working with the police, she was an 'impimpi'" (par 38).
}

While this case would seem to conform to the characteristics of a hate crime in terms of the hate motive, such acts are not specifically catered for in terms of general hate-crime definitions, which delineate specific categories of hate-crimes victims. As has been shown, the categories of victim in the United States, for example, have broadened over decades. Perhaps a broader category of victim could also be considered, taking into account the specific context of South African hate-crime legislation. The creation of specific hate-crime legislation in South Africa will assist in identifying, as well as stipulating suitable sentences for hate crimes. In this manner, hate crimes would be given added focus and the recognition these offences deserve.

\section{Conclusion}

Contrary to the position in the United States, no specific legislation exists regulating the prosecution of hate crimes in South Africa as yet, although the Government has ratified most of the international and regional conventions and agreements regarding discrimination. The Rome Statute was ratified 27 November 2000, and its obligations domesticated in The Implementation of the Rome Statute of the International Criminal Court Act 27 of 2002, which became law on 16 August 2002. Despite the fact that post-apartheid South Africa has been in a constitutional dispensation for the last twenty years, violent crime motivated in particular by prejudice based on ethnicity still exists. Offences driven by hate-crime biases (especially race and ethnicity) are so prevalent in our society (Harris "Arranging Prejudice: Exploring Hate Crime in post-apartheid South Africa" in Harris and Valji (eds) Race and Citizenship in Transition Series (2004) 8-10) that there is merit to the creation of hate-crime legislation, not only to protect the interests of all members of society, but also to comply with constitutional values. In this manner the message will be spread to all that these forms of violence motivated by prejudice will not be tolerated in our society. South Africa is in the process of introducing measures to address hate crimes in the form of the proposed Combating Hate Crimes, Hate Speech and Unfair Discrimination Bill, yet only after being called on to do so by the UN Committee on the Elimination of Racial Discrimination in 2006. This Bill aims to introduce the concept of hate crime to South African criminal law and also to develop measures to combat the crime. Similar to the United States' legislation, the South African Bill establishes a hate crime as any conduct which constitutes a recognized common-law or statutory offence with additional evidence of a discriminatory motive on the basis of characteristics that include, but are not limited to, nationality, race, religion and sexual orientation. In addition to the proposed legislation, victim-offender mediation has also been suggested as a possible solution as well as effective lawenforcement training to assist with the investigation and prosecution of such crimes (Perry "Where Do we Go from Here? Researching Hate Crime" 2003 
1 ICJ 44-45). South Africa is said to be committed to the fight against impunity, supplemented by a Constitution founded on the values of human dignity (s 10), equality (s 9), non-sexism and non-racialism (ss 9(3) and 16(2)(c)). Hate crimes fly directly in the face of these values. These constitutional values must be protected and more attention should be directed to the detection, prosecution and prevention of such crimes. Should the South African legislation be enacted, these values will indeed be protected by the provisions of the Bill.

Nina Mollema and Charnelle van der Bijl University of South Africa (UNISA) 